\title{
Non-Target Inhibition of Antioxidant Enzymes in Honey Bees (A. mellifera and A. florea) Upon Pesticide Exposure
}

\author{
${ }^{1}$ Amal Ahmed Berjawi, ${ }^{2}$ Syed Salman Ashraf and ${ }^{1}$ Mohammad Ali Al-Deeb \\ ${ }^{I}$ Department of Biology, United Arab Emirates University, Al-Ain, UAE \\ ${ }^{2}$ Department of Chemistry, Khalifa University, Abu Dhabi, UAE
}

\author{
Article history \\ Received: 20-02-2020 \\ Revised: 28-03-2020 \\ Accepted: 09-04-2020 \\ Corresponding Author: \\ Mohammad Ali Al-Deeb \\ Department of Biology, United \\ Arab Emirates University, Al- \\ Ain, UAE \\ Email: m_aldeeb@uaeu.ae.ae
}

\begin{abstract}
Understanding how different insecticides influence bee health is very essential. The aim of this work was to evaluate enzyme kinetics and inhibition by insecticides in Apis mellifera and Apis florea. Tested enzymes showed variable affinity to substrates. In $A$. florea, glutathione Stransferase (GST) showed significantly higher affinity for its 1-Chloro-2,4Dinitrobenzene (CDNB) substrate than in A. mellifera. Carbosulfan caused the highest inhibition to acetylcholinesterase (AChE) in both tested species in comparison with chlorpyrifos, dimethoate and pirimiphos-methyl. Our results show that exposure to insecticides is harmful to honey bees and results in negative effects on enzyme activity.
\end{abstract}

Keywords: Insecticide, Apis mellifera, Apis florea, Detoxifying Enzymes, Enzyme Kinetics

\section{Introduction}

Apis mellifera and Apis florea are two important plant pollinators and producers of honey in the United Arab Emirates and many other countries. Foraging honey bees are often exposed to insecticides while they are collecting nectar and pollen. In addition, honey bees are affected by Varroa mites, microsporidian parasites like Nosea apis, bacterial diseases such as American foulbrood and viral diseases for example deformed wing virus. Most risk assessment studies examining honey bees have focused mainly on the direct acute exposures to pesticides from spray drifts. However, it should be noticed that honey bees are also exposed to sublethal insecticide concentrations in the form of residues in nectar and pollen. The effects of insecticides on beneficial insects and honey bees can be deleterious and possibly lethal (Stapel et al., 2000). Many studies have shown that the pollen and nectar collected by honey bees and brought back to the hive contain significant concentrations of residues of different pesticides (including insecticides) (Greenpeace, 2014; Choudhary and Sharma, 2008; Chauzat et al., 2006; Pohorecka et al., 2012). Nectar insecticide residues are lower than pollen residues (Dively and Kamel, 2012; Choudhary and Sharma, 2008). Sanchez-Bayo and Goka (2014) have shown that pyrethroid and neonicotinoid insecticides pose the highest risk to bees by contact exposure with contaminated pollen. However, in many cases, the synergism of fungicides with the two above- mentioned classes of insecticides can result in much higher risks regardless of the low concentrations of their combined residues (Sanchez-Bayo and Goka, 2014). Additionally, there is concern when using systemic insecticides because these chemicals can translocate from the soil into the pollen and nectar of plants and as a result, they could be ingested by honey bees and other pollinators (Stoner and Eitzer, 2012). Furthermore, studies have shown that foliar-applied treatments and insecticides applied using drip irrigation during flowering can result in high concentrations of pesticide residues in the pollen and nectar of treated plants (Dively and Kamel, 2012). Therefore, it is not surprising that insecticide residues can be detected in honey. A study reported that insecticide residues were found in honey collected by both domesticated and wild bees. It was indicated that more apiary honeys were found to be contaminated with organochlorines and organophosphates at higher concentrations than honeys produced by wild Apis species (Khan et al., 2004).

It is well-established that upon exposure to various toxins and pollutants, insects have several mechanisms, including induction of detoxifying enzymes, to counteract the toxic effects of pesticides. Detoxifying enzymes, such as esterases, play roles in pesticide synergism and resistance (Ishaaya, 1993). Additionally, increased expression of detoxifying enzymes can provide insects with tolerance to some insecticides, such as pyrethroids (Kostaropoulos et al., 2001). In addition, several factors can induce the detoxifying enzymes in 
insects (Lee, 1991; Yu, 2004); for example, microsomal epoxidase and GST have been shown to be induced by cruciferous host plants, such as cabbage and their allelochemicals, in diamondback moth larvae ( $\mathrm{Yu}$ and Hsu, 1993). The induction of detoxifying enzyme activities can provide metabolic resistance against insecticides in many insect species ( $\mathrm{Li}$ et al., 2007). Studies have shown that GST and oxidase play roles in resistance in selected insecticides. Insecticide resistance primarily occurs due to changes in insect metabolic enzymes or to development of insecticideinsensitive target sites in the insect nervous system (Damayanthi and Karunaratne 2005). Qualitative and/or quantitative changes in GSTs and monooxygenases have been linked to increased insecticide metabolism. In a study, Yu (2004) noted that the decreased toxicity of carbaryl, permethrin and indoxacarb was most likely due to enhanced detoxification of these pesticides by microsomal oxidases and GSTs, which are involved in insecticide metabolism. Unlike the metabolic enzymes, which require high specificity, a high reaction rate and fine tuning by metabolites to carry out their functions, the detoxifying enzymes are slow, have a broad specificity and are essentially unidirectional catalysts that are able to react with a wide spectrum of xenobiotics that cells may encounter (Tang and Chang, 1996). GST enzymes have been reported to play a key role in the detoxification mechanism for insecticides and hence, they may contribute to insecticide resistance in economically important target insect species in diverse agricultural systems (Dou et al., 2006). GST is believed to be crucial because it is a major enzyme involved in phase II detoxification. Furthermore, significant alterations of the total and specific activities of this enzyme were noted during development of the branchiopod Artemia salina (Papadopoulos et al., 2004).

In the UAE, most of the A. mellifera honey bees are imported from Egypt and they differ from the European honey bee strains by having relatively higher tolerance to summer temperatures. Unlike A. mellifera bees that are kept in Langstroth hives, the A. florea honey bees live in open nests and small colonies that are not maintained by beekeepers. The aims of this in vitro study were (1) to measure enzyme kinetics in $A$. mellifera and A. florea and (2) to study enzyme inhibition by insecticides.

\section{Materials and Methods}

Insects

A. mellifera honey bees were obtained from the beehives of the Abu-Dhabi Food Control Authority (ADFCA) in Al-Ain, UAE. A. florea adult bees were collected from wild colonies in Al-Ain, UAE.

\section{Chemicals}

Reduced glutathione (GSH), sodium bicarbonate $\left(\mathrm{NaHCO}_{3}\right)$, Fast Blue B salt (o-dianisidine, tetrazotized zinc chloride complex) and hydrogen peroxide (30\%) [Sigma-Aldrich (St. Louis, MO, USA)]; Acetylthiocholine iodide (ATCh), 5, 5-dithio-bis-(2nitrobenzoic acid) (DTNB) and 1-naphthyl acetate (1NA) [Sigma]. 1-Chloro-2,4-Dinitrobenzene (CDNB) and 3,3,5,5-Tetra-Methylbenzidine (TMBZ) [Aldrich (Steinheim, Germany)]. Bovine serum albumin (BSA) and the Bradford dye reagent [Thermo Scientific (Rockford, IL, USA)]; Insecticide analytical standards carbosulfan, chlorpyrifos, dimethoate and pirimiphosmethyl [Fluka/Sigma-Aldrich (St. Louis, MO, USA)].

\section{Insecticide Preparation}

All insecticide active ingredients were first dissolved in absolute ethanol then diluted in distilled water to attain the appropriate concentrations.

\section{Enzyme Preparation}

Adults of A. mellifera and A. florea were homogenized manually (with pestle and mortar) in phosphate buffer for the GST, esterase and oxidase enzyme assays. For the AChE assay, heads of A. mellifera and A. florea adults were homogenized manually in phosphate buffer. All homogenates were centrifuged at $16,500 \mathrm{xg}$ for $10 \mathrm{~min}$ at $4^{\circ} \mathrm{C}$ as described by Smirle (1990). The protein concentrations of insect homogenates were determined according to the method of Bradford (1976) using bovine serum albumin as a standard.

\section{Enzyme Kinetic Parameters}

GST

The GST activity toward the CDNB substrate was determined according to Habig et al. (1974). Briefly, 250 $\mu \mathrm{L}$ of diluted enzyme preparation, $150 \mu \mathrm{L}$ of $8.13 \mathrm{mM}$ GSH and $10 \mu \mathrm{L}$ of CDNB with a range of final concentrations $(0.54,0.27,0.13,0.068,0.034,0.017$ $\mathrm{mM}$ ) were mixed with $490 \mu \mathrm{L}$ of $0.1 \mathrm{M}$ potassium phosphate buffer ( $\mathrm{pH}$ 7.2) and $10 \mu \mathrm{L}$ CDNB. The nonenzymatic reaction of $\mathrm{CDNB}$ and GSH measured without homogenate served as a control. The absorbance was recorded at $340 \mathrm{~nm}$ for the CDNB substrate using a spectrophotometer every 2 min for 10 min and converted into nmol CDNB conjugated $/ \mathrm{min} / \mathrm{mg}$ protein with extinction coefficient $\varepsilon_{340 \mathrm{~nm}}=9.6 \mathrm{mM}^{-1} \mathrm{~cm}^{-1}$ (Wu et al., 2008; Dou et al., 2006).

\section{General Esterase}

Esterase activity was assayed using 1-NA (1-naphthyl acetate) as a substrate as described by Damayanthi and Karunaratne (2005). A volume of $250 \mu \mathrm{L}$ of diluted homogenates, $300 \mu \mathrm{L}$ of $7.8 \mathrm{mM}$ Fast Blue B and $10 \mu \mathrm{L}$ 
of 1-NA with different concentrations $(0.1,0.026,0.013$ 0.0064 and $0.00322 \mathrm{mM}$ ) were mixed with $340 \mu \mathrm{L}$ of 0.1 $\mathrm{M}$ potassium phosphate buffer ( $\mathrm{pH}$ 7.2). The control was a non-enzymatic reaction, which contained no homogenate. The absorbance was recorded at $620 \mathrm{~nm}$ for the $\alpha$-NA substrate using a spectrophotometer every 2 $\min$ for $10 \mathrm{~min}$ and converted into nmol $\alpha-\mathrm{NA}$ conjugated $/ \mathrm{min} / \mathrm{mg}$ protein with extinction coefficient $\varepsilon_{620 \mathrm{~nm}}=2.222 \mathrm{mM}^{-1} \mathrm{~cm}^{-1}(\mathrm{He}, 2003)$.

\section{AChE}

Acetylcholinesterase activity was measured using acetylthiocholine iodide (ATCh) as a substrate according to Ellman et al. (1961). A volume of $100 \mu \mathrm{L}$ of homogenate, $12 \mu \mathrm{L}$ of ATCh of different concentrations $(1.057,0.52,0.26,0.13,0.065,0.037$ and $0.016 \mathrm{mM})$ and $30 \mu \mathrm{L}$ of $0.33 \mathrm{mM}$ DTNB (Ellman's reagent) were mixed with $758 \mu \mathrm{L}$ of $0.1 \mathrm{M}$ potassium phosphate buffer (pH 7.2). The control was a non-enzymatic reaction, which contained no homogenate. The absorbance was measured at $414 \mathrm{~nm}$ for the ATCh substrate using a spectrophotometer every $2 \mathrm{~min}$ for $10 \mathrm{~min}$ and converted into $\mathrm{nmol}$ ATCh conjugated $/ \mathrm{min} / \mathrm{mg}$ protein with extinction coefficient $\varepsilon_{414 \mathrm{~nm}}=1.36 \times 10^{4} \mathrm{mM}^{-1} \mathrm{~cm}^{-1}$ (Ellman et al., 1961).

\section{General Oxidase}

Oxidase activity was obtained using 3,3,5,5-TetraMethylbenzidine (TMBZ) as a substrate as described by Tiwari et al. (2011). The assay was run as follows: $100 \mu \mathrm{L}$ of the homogenate, $100 \mu \mathrm{L}$ of TMBZ of different concentrations $(0.184,0.092,0.045,0.022$, 0.011 and $0.005 \mathrm{mM}$ ) and $25 \mu \mathrm{L}$ of $3 \% \mathrm{H}_{2} \mathrm{O}_{2}$ were mixed with $675 \mu \mathrm{L}$ of $0.25 \mathrm{M}$ of diluted sodium acetate buffer ( $\mathrm{pH} 5)$. The buffer was diluted to avoid the blockage of the substrate position on the enzyme by sodium ions. The control was a non-enzymatic reaction, which contained no homogenate. The absorbance was recorded at $620 \mathrm{~nm}$ for the TMBZ substrate using a spectrophotometer every $2 \mathrm{~min}$ for $10 \mathrm{~min}$ and converted into nmol TMBZ conjugated $/ \mathrm{min} / \mathrm{mg}$ protein with extinction coefficient $\varepsilon_{620 \mathrm{~nm}}=3.9 \times 10^{4} \mathrm{mM}^{-1} \mathrm{~cm}^{-1}$ (Josephy et al., 1982).

\section{Enzyme Inhibition}

Enzyme inhibition in vitro experiments were conducted on AChE and general esterase. Four insecticides were tested: carbosulfan $(0.310 \mathrm{nM})$, chlorpyrifos $(0.437 \mathrm{nM})$, pirimiphos-methyl $(0.773 \mathrm{nM})$ and dimethoate $(0.95 \mu \mathrm{M})$.

\section{AChE}

A volume of $33.3 \mu \mathrm{L}$ of homogenate was added with $15 \mu \mathrm{L}$ of an insecticide at the concentrations listed in the esterase inhibition assay. The mixture was incubated for
$10 \mathrm{~min}$ at room temperature. Then, $199.3 \mu \mathrm{L}$ of a mixture $(10 \mu \mathrm{L}$ of $0.33 \mathrm{mM}$ DTNB and $189.3 \mu \mathrm{L}$ of 0.1 $\mathrm{M}$ potassium phosphate buffer ( $\mathrm{pH}$ 7.2)) was added and $4 \mu \mathrm{L}$ of $1.057 \mathrm{mM}$ ATCh was then added. The whole mixture was incubated for another $45 \mathrm{~min}$ at room temperature. The control was a non-enzymatic reaction, which contained no homogenate. The absorbance was recorded at $414 \mathrm{~nm}$ for the ATCh substrate using a microplate reader. The change in absorbance was measured as an endpoint reaction (Ellman et al., 1961).

\section{General Esterase}

A volume of $83.3 \mu \mathrm{L}$ of homogenate was added, followed by $15 \mu \mathrm{L}$ of an insecticide with the following concentrations: (carbosulfan $(0.310 \mathrm{nM})$, chlorpyrifos (0.437 nM), pirimiphos-methyl $(0.773 \mathrm{nM})$ and dimethoate $(0.95 \mu \mathrm{M})$. The mixture was incubated for $10 \mathrm{~min}$ at room temperature, after which $120 \mu \mathrm{L}$ of a mixture $[3.33 \mu \mathrm{L}$ of $0.1 \mathrm{mM} 1-\mathrm{NA}+116.6 \mu \mathrm{L}$ of $0.1 \mathrm{M}$ potassium phosphate buffer $(\mathrm{pH}$ 7.2)] was added and $100 \mu \mathrm{L}$ of $7.8 \mathrm{mM}$ Fast Blue B was then added. The whole mixture was incubated for another $10 \mathrm{~min}$ at room temperature. The control was a non-enzymatic reaction, which contained no homogenate. The absorbance was recorded at $620 \mathrm{~nm}$ for 1-NA using a microplate reader. The change in absorbance was measured as an endpoint reaction ( $\mathrm{He}, 2003)$.

\section{Kinetics Parameters of Inhibition $\left(K_{m}, V_{\max }\right.$ and $\left.K_{i}\right)$}

The inhibition kinetics of general esterases and AChE were calculated with carbosulfan, chlorpyrifos and pirimiphos-methyl. The calculations of the kinetics constants $\left(\mathrm{K}_{\mathrm{m}}, \mathrm{V}_{\max }\right.$ and $\left.\mathrm{K}_{\mathrm{i}}\right)$ of esterase and $\mathrm{AChE}$ were performed using double-reciprocal plots, obtained by plotting $1 / \mathrm{v}_{0}$ vs $1 /[\mathrm{S}]$ to determine the intercepts and the slopes of the linear transformation. $K_{i}$ is the inhibitor constant, which is the concentration required to produce half maximal inhibition. The same esterase and AChE inhibition assay protocols were followed to conduct the experiments in A. mellifera and A. florea using a microplate reader. The concentration of each insecticide was tested with a range of substrate concentrations of 1 -NA $(0.1,0.026,0.013,0.0064$ and $0.00322 \mathrm{mM})$ and ATCh $(1.057,0.52,0.26,0.13,0.065$, 0.037 and $0.016 \mathrm{mM}$ ).

\section{Statistical Analysis}

Differences between treatments were tested using analysis of variance $t$ test and Analysis of Variance (ANOVA) using SAS software (SAS Institute Inc., Cary, NC, USA). Means were separated in significant ANOVA using Fisher Least Significant Difference (LSD). The significance value was set at $P<0.05$. Each enzyme assay was conducted at least three times. 


\section{Results}

\section{Enzyme Kinetics}

$K_{m}$

The GST of $A$. florea adults showed significantly higher affinity for the enzyme substrate $(18.67 \pm 0.67$ $\mathrm{mM}$ ) than adults of $A$. mellifera $(24.97 \pm 0.52 \mathrm{mM})$ (Table 1). However, the general esterase enzymes of $A$. florea showed a significantly lower substrate affinity $(0.63 \pm 0.026 \mathrm{mM})$ compared to A. mellifera $(0.39 \pm 0.020$ $\mathrm{mM})$. The oxidase showed no significant differences between $A$. mellifera and A. florea in terms of substrate affinity (33.3 \pm 1.70 and $26.62 \pm 2.57 \mathrm{mM}$, respectively).

$V_{\max }$

Significant differences were found in the $\mathrm{V}_{\max }$ values between adults of $A$. mellifera and A. florea for GST $(195 \pm 18.77$ and $130 \pm 15.53 \mathrm{nmol} / \mathrm{min}$, respectively) and general esterases $(693.9 \pm 37.53$ and $830.5 \pm 22.57$ $\mathrm{pmol} / \mathrm{min}$, respectively) (Table 1). However, the difference between the two species was not significant for the oxidase ( $49.6 \pm 2$ and $56.7 \pm 1 \mathrm{nmol} / \mathrm{min}$, respectively).

\section{Specific Activity}

No significant differences were found in the specific activities between adults of A. mellifera and A. florea for GST $(156.8 \pm 31.10$ and $117.1 \pm 22.46 \mathrm{nmol} / \mathrm{min} / \mathrm{mg}$ protein, respectively), general esterase $(53.89 \pm 2.909$ and $61.18 \pm 2.776 \mathrm{nmol} / \mathrm{min} / \mathrm{mg}$ protein, respectively) and oxidase $\quad(0.0093 \pm 0.00040$ and $0.0099 \pm 0.00003$ $\mathrm{pmol} / \mathrm{min} / \mathrm{mg}$ protein, respectively) (Table 1 ).

\section{Enzyme Inhibition}

Carbosulfan, chlorpyrifos and pirimiphos-methyl inhibited AChE and general esterases in both $A$. mellifera and A. florea at different levels. In A. mellifera, carbosulfan had the highest inhibitory effect $(69.76 \%)$ on AChE activity followed by chlorpyrifos (60.46\%) and pirimiphos-methyl (44.18\%) (Table 2). The specific activity of AChE when incubated separately with carbosulfan, pirimiphos-methyl and chlorpyrifos was $13 \pm 0.1, \quad 17 \pm 0.6$ and $24 \pm 0.3 \mathrm{pmol} / \mathrm{min} / \mathrm{mg}$ protein, respectively. However, in A. florea, pirimiphos-methyl caused the highest inhibition (80.65\%) of AChE followed by carbosulfan (77.42) and chlorpyrifos (70.97). This was demonstrated by the lower specific activity of the enzyme in the presence of pirimiphos-methyl, carbosulfan and chlorpyrifos, which was $12 \pm 0.1,14 \pm 0.4$ and $18 \pm 0.05$ $\mathrm{pmol} / \mathrm{min} / \mathrm{mg}$ protein, respectively, compared to the control $(43 \pm 0.3 \mathrm{pmol} / \mathrm{min} / \mathrm{mg}$ protein). Similar results were found with general esterase (Table 2). In $A$. mellifera, carbosulfan had the highest significant inhibitory effect on the enzyme $(56.82 \%)$ followed by pirimiphos-methyl $(46.49 \%)$ and chlorpyrifos $(35.72 \%)$.
With carbosulfan, the specific activity was $0.57 \pm 0.0120$, compared to chlorpyrifos $(0.85 \pm 0.0186)$ and pirimiphosmethyl $(0.71 \pm 0.0058 \mu \mathrm{mol} / \mathrm{min} / \mathrm{mg}$ protein $)$. When incubated with one of the three insecticides, the enzyme specific activity was significantly lower than the control $(1.327 \pm 0.0033)$. However, in A. florea, pirimiphosmethyl had the highest significant inhibitory effect $(66.73 \%)$, with a specific activity of $0.34 \pm 0.0029$ $\mu \mathrm{mol} / \mathrm{min} / \mathrm{mg}$ protein followed by carbosulfan $(52.46 \%$; $0.49 \pm 0.0033 \mu \mathrm{mol} / \mathrm{min} / \mathrm{mg}$ protein) and chlorpyrifos $(46.96 \% ; 0.55 \pm 0.0152 \mu \mathrm{mol} / \mathrm{min} / \mathrm{mg}$ protein) (Table 2$)$.

\section{Kinetics Parameters of Inhibition}

\section{AChE}

The presence of $0.310 \mathrm{nM}$ carbosulfan in the reaction mixture resulted in an inhibition of $\mathrm{AChE}$ activity in A. mellifera and A. florea. Carbosulfan decreased the $\mathrm{V}_{\max }$ by $51 \%$ and increased the $\mathrm{K}_{\mathrm{m}}$ by $61 \%$ in A. mellifera. However, carbosulfan decreased the $\mathrm{V}_{\max }$ by $61 \%$ and increased the $\mathrm{K}_{\mathrm{m}}$ by $79 \%$ in $A$. florea compared with control values in the absence of the insecticide (Table 3). The $\mathrm{K}_{\mathrm{i}}$ and $\mathrm{K}_{\mathrm{i}}{ }^{\prime}$ of $0.071 \pm 0.005$ and $0.290 \pm 0.017 \mathrm{nM}$ in A. mellifera and $0.028 \pm 0.002$ and $0.197 \pm 0.010 \mathrm{nM}$ in $A$. florea, respectively, were calculated for AChE inhibition.

The inclusion of $0.437 \mathrm{nM}$ chlorpyrifos in the reaction for both $A$. mellifera and $A$. florea led to a significant inhibition in AChE activity. Compared with control values, chlorpyrifos decreased the $\mathrm{V}_{\max }$ by $44 \%$, while the $\mathrm{K}_{\mathrm{m}}$ was almost the same in A. mellifera. However, the $\mathrm{V}_{\text {max }}$ decreased by $68 \%$ and the $\mathrm{K}_{\mathrm{m}}$ increased by $74 \%$ in $A$. florea (Table 3). The $\mathrm{K}_{\mathrm{i}}$ value of chlorpyrifos was found to be $11.13 \pm 0.502 \mathrm{nM}$ in $A$. mellifera $\mathrm{AChE}$ while $\mathrm{K}_{\mathrm{i}}$ and $\mathrm{K}_{\mathrm{i}}^{\prime}$ values were $0.040 \pm 0.002$ and $0.200 \pm 0.021 \mathrm{nM}$ in $A$. florea AChE, respectively.

Similarly, $0.773 \mathrm{nM}$ of pirimiphos-methyl was incubated with the AChE assay mixture for both $A$. mellifera and $A$. florea. The results show that pirimiphosmethyl caused significant inhibition of AChE activity in both species. In A. mellifera, the $\mathrm{K}_{\mathrm{m}}$ increased by $54 \%$ and the $\mathrm{V}_{\max }$ decreased by $43 \%$. Moreover, the $\mathrm{K}_{\mathrm{i}}$ and $\mathrm{K}_{\mathrm{i}}{ }^{\prime}$ values of $A$. mellifera $\mathrm{AChE}$ were $0.273 \pm 0.012$ and $1.022 \pm 0.071 \mathrm{nM}$, respectively (Table 3 ). In A. florea, the $\mathrm{K}_{\mathrm{m}}$ increased by $42 \%$ and the $\mathrm{V}_{\max }$ was decreased by $74 \%$. In addition, the $\mathrm{K}_{\mathrm{i}}$ and $\mathrm{K}_{\mathrm{i}}$ ' values of $A$. florea $\mathrm{AChE}$ were $0.141 \pm 0.012$ and $0.278 \pm 0.030 \mathrm{nM}$, respectively.

\section{General Esterase}

Adding $0.310 \mathrm{nM}$ of carbosulfan to the reaction mixture resulted in an inhibition of general esterase activity in $A$. mellifera and A. florea. Carbosulfan decreased the $\mathrm{V}_{\max }$ by $55 \%$ and decreased the $\mathrm{K}_{\mathrm{m}}$ by $81 \%$ in A. mellifera esterase, while it decreased the $\mathrm{V}_{\max }$ by $44 \%$ and increased the $\mathrm{K}_{\mathrm{m}}$ by $60 \%$ in $A$. florea 
esterase compared with control values in the absence of the insecticide (Table 3). The $\mathrm{K}_{\mathrm{i}}$ and $\mathrm{K}_{\mathrm{i}}^{\prime}$ values of $0.098 \pm 0.007$ and $0.258 \pm 0.011 \mathrm{nM}$ in A. mellifera, respectively and $0.092 \pm 0.008$ and $0.397 \pm 0.025 \mathrm{nM}$ in $A$. florea, respectively, were calculated for carbosulfan inhibition of general esterase activity.

For both A. mellifera and A. florea, adding $0.437 \mathrm{nM}$ of chlorpyrifos to the reaction led to a significant inhibition in the general esterase activity. Compared with control values, chlorpyrifos decreased both the $\mathrm{V}_{\max }$ by $52 \%$ and the $\mathrm{K}_{\mathrm{m}}$ by $89 \%$ in A. mellifera. However, the $\mathrm{V}_{\max }$ decreased by $42 \%$ and the $\mathrm{K}_{\mathrm{m}}$ increased by $60 \%$ in $A$. florea (Table 3 ). The $\mathrm{K}_{\mathrm{i}}$ and $\mathrm{K}_{\mathrm{i}}^{\prime}$ values of $0.350 \pm 0.029$ and $0.408 \pm 0.036 \mathrm{nM}$ in $A$. mellifera, respectively and $0.132 \pm 0.014$ and $0.642 \pm 0.052$ $\mathrm{nM}$ in $A$. florea, respectively, were calculated for general esterase inhibition by chlorpyrifos.

Table 1: Comparison of enzyme kinetics (Mean \pm SE) in A. mellifera and A. florea (in vitro)

\begin{tabular}{llll}
\hline & & A. mellifera (adult) & A.florea (adult) \\
\hline $\mathrm{K}_{\mathrm{m}}(\mathrm{mM})$ & GST & $24.97 \pm 0.52 \mathrm{a}$ & $18.67 \pm 0.67 \mathrm{~b}$ \\
& General Esterase & $0.39 \pm 0.020 \mathrm{~b}$ & $0.63 \pm 0.026 \mathrm{a}$ \\
& General Oxidase & $33.3 \pm 1.70 \mathrm{a}$ & $26.62 \pm 2.57 \mathrm{a}$ \\
$\mathrm{V}_{\max }$ & & & \\
$(\mathrm{nmol} / \mathrm{min})$ & GST & $195 \pm 18.77 \mathrm{a}$ & $130 \pm 15.53 \mathrm{~b}$ \\
& General Esterase & $693.9 \pm 37.53 \mathrm{~b}$ & $830.5 \pm 22.57 \mathrm{a}$ \\
Specific activity (nmol/min/mg protein) & General Oxidase* & $49.6 \pm 2 \mathrm{a}$ & $56.7 \pm 1 \mathrm{a}$ \\
& GST & $156.8 \pm 31.10 \mathrm{a}$ & $117.1 \pm 22.46 \mathrm{a}$ \\
& General Esterase & $53.89 \pm 2.909 \mathrm{a}$ & $61.18 \pm 2.776 \mathrm{a}$ \\
& General Oxidase & \\
& & $0.0093 \pm 0.00040 \mathrm{a}$ & $0.0099 \pm 0.00003 \mathrm{a}$
\end{tabular}

Mean values within one row followed by the same letter are not significantly different from each other according to $t$ test, $(P>0.05)$. GST $=$ Glutathione S-Transferase, $\mathrm{AChE}=$ Acetylcholinesterase $. \mathrm{K}_{\mathrm{m}}=$ Substrate concentration at which the rate was half of maximum velocity $\left(\mathrm{V}_{\max }\right)$; ${ }^{*}$ Units of $\mathrm{V}_{\max }$ are in $\mathrm{pmol} / \mathrm{min}$. ** Units of specific activity are in $\mathrm{pmol} / \mathrm{min} / \mathrm{mg}$ protein.

Table 2: Enzyme inhibition caused by exposure to insecticides and measured as specific enzyme activity (Mean $\pm \mathrm{SE}) \mathrm{in} \mathrm{nmol} / \mathrm{min} / \mathrm{mg}$ protein of $A$. mellifera and A florea $\mathrm{AChE}$ and general esterase after 10 min incubation with insecticides (in vitro).

\begin{tabular}{|c|c|c|c|c|c|c|c|c|}
\hline \multirow[b]{2}{*}{ Insecticide } & \multicolumn{4}{|l|}{$\mathrm{AChE}$} & \multicolumn{4}{|l|}{ General Esterase } \\
\hline & A. mellifera & $\%$ & A. florea & $\%$ & A. mellifera & $\%$ & A. florea & $\%$ \\
\hline Control & $43 \pm 0.3 \mathrm{a}$ & 0 & $62 \pm 1.6 \mathrm{a}$ & 0 & $1.327 \pm 0.0033 \mathrm{a}$ & 0 & $1.037 \pm 0.0033 \mathrm{a}$ & 0 \\
\hline Carbosulfan (0.310 nM) & $13 \pm 0.1 \mathrm{e}$ & 69.76 & $14 \pm 0.4 \mathrm{~d}$ & 77.42 & $0.573 \pm 0.0120 \mathrm{e}$ & 56.82 & $0.493 \pm 0.0033 d$ & 52.46 \\
\hline Chlorpyrifos (0.437 nM) & $24 \pm 0.3 c$ & 44.18 & $18 \pm 0.5 \mathrm{c}$ & 70.97 & $0.853 \pm 0.0185 \mathrm{c}$ & 35.72 & $0.550 \pm 0.0152 \mathrm{c}$ & 46.96 \\
\hline Pirimiphos-methyl (0.773 nM) & $17 \pm 0.6 \mathrm{~d}$ & 60.46 & $12 \pm 0.1 d$ & 80.65 & $0.710 \pm 0.0057 \mathrm{~d}$ & 46.49 & $0.345 \pm 0.0029 \mathrm{e}$ & 66.73 \\
\hline Dimethoate $(0.95 \mu \mathrm{M})$ & $38 \pm 0.3 b$ & 11.63 & $57 \pm 0.3 b$ & 8.06 & $1.307 \pm 0.0066 \mathrm{ab}$ & 1.51 & $0.996 \pm 0.0120 \mathrm{ab}$ & 3.95 \\
\hline
\end{tabular}

Mean values within one column followed by the same letter are not significantly different from each other according to ANOVA, LSD test
$(P>0.05) . \%=$ percentage of enzyme inhibition compared to the control. AChE = Acetylcholinesterase

Table 3: Inhibition kinetics parameters (Mean \pm SE) of A. mellifera and A. florea AChE and general esterase using ATCh / 1-NA, respectively as substrates with the three insecticides (in vitro)

\begin{tabular}{llllll}
\hline & & Control & Carbosulfan & Chlorpyrifos & Pirimiphos-methyl \\
\hline A. mellifera & & & & & \\
AChE & $\mathrm{K}_{\mathrm{m}}(\mathrm{mM})$ & $0.023 \pm 0.002$ & $0.059 \pm 0.006$ & $0.026 \pm 0.002$ & $0.050 \pm 0.005$ \\
& $\mathrm{~V}_{\max }(\mathrm{nmol} / \mathrm{min})$ & $0.265 \pm 0.018$ & $0.129 \pm 0.004$ & $0.148 \pm 0.009$ & $0.151 \pm 0.007$ \\
& $\mathrm{~K}_{\mathrm{i}}(\mathrm{nM})$ & -- & $0.071 \pm 0.005$ & $11.13 \pm 0.502$ & $0.273 \pm 0.012$ \\
& $\mathrm{~K}_{\mathrm{i}}^{\prime}(\mathrm{nM})$ & -- & $0.290 \pm 0.017$ & -- & $1.022 \pm 0.071$ \\
General Esterase & $\mathrm{K}_{\mathrm{m}}(\mathrm{mM})$ & $0.037 \pm 0.0028$ & $0.007 \pm 0.0005$ & $0.004 \pm 0.0002$ & $0.008 \pm 0.0007$ \\
& $\mathrm{~V}_{\max }(\mu \mathrm{mol} / \mathrm{min})$ & $5.905 \pm 0.4150$ & $2.672 \pm 0.1550$ & $2.840 \pm 0.2110$ & $1.752 \pm 0.0700$ \\
& $\mathrm{~K}_{\mathrm{i}}(\mathrm{nM})$ & -- & $0.098 \pm 0.0070$ & $0.350 \pm 0.0290$ & $0.112 \pm 0.0060$ \\
A. florea & $\mathrm{K}_{\mathrm{i}}^{\prime}(\mathrm{nM})$ & -- & $0.258 \pm 0.0110$ & $0.408 \pm 0.0360$ & $0.336 \pm 0.0230$ \\
AChE & & & & \\
& $\mathrm{K}_{\mathrm{m}}(\mathrm{mM})$ & $0.062 \pm 0.005$ & $0.290 \pm 0.020$ & $0.238 \pm 0.021$ & $0.107 \pm 0.013$ \\
& $\mathrm{~V}_{\max }(\mathrm{nmol} / \mathrm{min})$ & $0.246 \pm 0.010$ & $0.095 \pm 0.009$ & $0.079 \pm 0.007$ & $0.065 \pm 0.002$ \\
General Esterase & $\mathrm{K}_{\mathrm{i}}(\mathrm{nM})$ & -- & $0.028 \pm 0.002$ & $0.040 \pm 0.002$ & $0.141 \pm 0.012$ \\
& $\mathrm{~K}_{\mathrm{i}}^{\prime}(\mathrm{nM})$ & -- & $0.197 \pm 0.010$ & $0.200 \pm 0.021$ & $0.278 \pm 0.030$ \\
& $\mathrm{~K}_{\mathrm{m}}(\mathrm{mM})$ & $0.002 \pm 0.0001$ & $0.005 \pm 0.0004$ & $0.005 \pm 0.0006$ & $0.009 \pm 0.0004$ \\
& $\mathrm{~V}_{\max }(\mu \mathrm{mol} / \mathrm{min})$ & $4.813 \pm 0.2850$ & $2.680 \pm 0.1870$ & $2.800 \pm 0.1530$ & $1.896 \pm 0.0970$ \\
& $\mathrm{~K}_{\mathrm{i}}(\mathrm{nM})$ & -- & $0.092 \pm 0.0080$ & $0.132 \pm 0.0140$ & $0.067 \pm 0.0020$ \\
& $\mathrm{~K}_{\mathrm{i}}^{\prime}(\mathrm{nM})$ & -- & $0.397 \pm 0.0250$ & $0.642 \pm 0.0520$ & $0.505 \pm 0.0550$ \\
\hline
\end{tabular}

$\overline{\mathrm{AChE}}=$ Acetylcholinesterase. $\mathrm{K}_{\mathrm{m}}=$ Substrate concentration at which the rate was half of maximum velocity $\left(\mathrm{V}_{\max }\right) . \mathrm{K}_{\mathrm{i}}=$ Inhibitor constant, which is the concentration required to produce half maximum inhibition 
Similarly, when $0.773 \mathrm{nM}$ of pirimiphos-methyl was added to the reaction it caused inhibition in general esterase activity for both species. In A. mellifera, the $\mathrm{K}_{\mathrm{m}}$ decreased by $78 \%$ and the $\mathrm{V}_{\max }$ also decreased by $70 \%$. Moreover, the $\mathrm{K}_{\mathrm{i}}$ and $\mathrm{K}_{\mathrm{i}}^{\prime}$ values of $A$. mellifera are $0.112 \pm 0.006$ and $0.336 \pm 0.023 \mathrm{nM}$, respectively (Table 3). In A. florea, the $\mathrm{K}_{\mathrm{m}}$ increased by $78 \%$ and the $\mathrm{V}_{\max }$ was decreased by $61 \%$. In addition, the $\mathrm{K}_{\mathrm{i}}$ and $\mathrm{K}_{\mathrm{i}}{ }^{\prime}$ values for the inhibition of general esterase activity in A. florea are $0.067 \pm 0.002$ and $0.505 \pm 0.055 \mathrm{nM}$, respectively.

\section{Discussion}

\section{Enzyme Kinetics}

The results of the current study show that the $A$. florea GST has a higher affinity for its substrate (1.3fold) than the GST of the A. mellifera and this is probably a result of species differences or the exclusive feeding of A. florea on wild plants unlike A. mellifera bees, which receive some artificial feeds such as sugar syrups by beekeepers. Additionally, the results demonstrate that the $A$. mellifera general esterase enzymes has a higher affinity (1.6-fold) for the substrate compared to the general esterase of A. florea. In general, the differences in substrate affinities could be related to interspecific differences. Furthermore, insect species have different dietary needs and show differences in body size and this might be the case in the current study where A. florea is much smaller than A. mellifera. Vanhaelen et al. (2004) performed a study on the purification and characterization of Glutathione Stransferases (GSTs) from two syrphid flies (Syrphus ribesii and Myathropa florea). Their results showed that the specific activity of GST toward CDNB was 1.7-fold higher for $S$. ribesii than $M$. florea. With regard to kinetics, $M$. florea had higher $\mathrm{K}_{\mathrm{m}}$ values than those from $S$. ribesii, with values being $2.6,1.4$ and 2-fold higher for GSH, CDNB and DNIB, respectively, indicating differences among species. Also, the $\mathrm{V}_{\max }$ values were higher for $S$. ribesii, with ratios of 3.2, 5.3 and 1.8 for GSH, CDNB and DNIB, respectively, compared to $M$. florea.

\section{Enzyme Inhibition}

In this study, the tested insecticide concentrations were lower than the ones applied on plants in the field. Carbosulfan and pirimiphos-methyl caused higher inhibition in AChE and general esterase enzymes in both A. mellifera and A. florea. This indicates that these two honey bee species are at risk in the fields treated with carbosulfan and pirimiphos-methyl. These results agree with a published laboratory bioassay showing that carbosulfan was the most toxic insecticide to A. mellifera (Husain et al., 2014). Another study showed that carbosulfan is toxic to A. mellifera (Akca et al., 2009). In fact, pesticide damage becomes more aggravated when bees visit different plants during their foraging trips and therefore, they potentially are exposed to mixtures of pesticides. It was reported that honey bees travel more than 5-6 km and even longer distances to collect pollen and nectar (Hagler et al., 2011; Visscher and Seeley 1982).

\section{Enzyme Inhibition Kinetics}

In the current study, insecticides were tested to investigate their potential role in inhibiting $\mathrm{AChE}$ and general esterase activities. Generally, carbosulfan, chlorpyrifos and pirimiphos-methyl inhibited AChE and esterase. Detoxifying enzymes and target alteration are equally important mechanisms of insecticide degradation (Pasay et al., 2009). AChE is of interest because it is the target enzyme for organophosphate and carbamate insecticides in the central nervous system (Wang et al., 2004) and its role in cholinergic synapses is essential for life. Several studies have been performed on insect $\mathrm{AChE}$ to explore the relationship between AChE alteration and insect resistance (especially to carbamates and organophosphates) (Chai et al., 2007). Price (1988) explained that there are many factors that may affect the susceptibility of AChE to specific insecticides, such as cuticle penetration and metabolic processes. Therefore, AChE sensitivity does not necessarily indicate that insects will be sensitive to a particular chemical when it is used as an insecticide. Substrate inhibition at a high concentration is a normal phenomenon for $\mathrm{AChE}$ and is most likely due to the binding of excess substrate to the peripheral (allosteric) anionic site to form an enzymesubstrate complex (Hai-Hua et al., 2005). Carbamate insecticides inhibit AChE by adding a carbamyl group on the enzyme, which completely inactivates the enzyme (Leibson and Lifshitz, 2008). Moreover, organophosphate compounds inhibit cholinesterases (Kamanyire and Karalliedde, 2004), leading to the accumulation of acetylcholine. The inhibition of AChE causes overstimulation of nicotinic and muscarinic acetylcholine receptors (Sogorb and Vilanova, 2002).

The poisoning of $A$. mellifera arising from the agricultural use of pesticides has been monitored long time ago. In the United Kingdom the measurement of bee head AChE inhibition was used as an indicator of organophosphate insecticide poisoning (Westlake et al., 1985). In 1978, there were widespread reports of serious poisoning associated with honey bees foraging on oilseed rape to which triazophos (organophosphates) had been applied. Investigation of these incidents showed that AChE inhibition was apparently reversible after triazophos poisoning. Additionally, Suh and Shim (1988) reported that GST (CDNB conjugation) activity was significantly induced by diazinon and moderately induced by permethrin (Suh and Shim, 1988). Westlake et al. (1985) reported that lethal insecticide treatment of bees 
with most carbamate and organophosphate compounds resulted in significant $\mathrm{AChE}$ inhibition. In the current study, pirimiphos-methyl was the most potent inhibitor of the esterase enzymes in both $A$. mellifera and $A$. florea. Furthermore, the presence of carbosulfan, chlorpyrifos and pirimiphos-methyl in the incubation mixture with the enzymes at different substrate (ATCh and 1-NA) concentrations for $\mathrm{AChE}$ and esterase, respectively, exhibited mixed inhibition patterns. However, chlorpyrifos exhibited a non-competitive inhibition because the $\mathrm{K}_{\mathrm{m}}$ value was not affected. Noncompetitive inhibition is considered a mixed inhibition. Generally, this indicates that the insecticide directly binds to the AChE and esterase active site and allosteric site as well, reducing the concentration of free enzyme available for 1-NA/ATCh binding. This potentially allows the insecticide to persist in a honey bee for a longer period of time because of the lower activity of detoxification achieved by AChE and esterase. He (2003) conducted a study using a continuous spectrophotometric assay for the determination of diamondback moth esterase activity. His results illustrated that the 1-NA exhibited a competitive inhibition toward azadirachtin. However, the current study is different from the work of He (2003) because the inhibiting insecticide was a plant extract (azadirachtin). As a result, they obtained competitive inhibition patterns while mixed and non-competitive inhibitions were observed in the present study. In addition, the current study provided the parameters of the inhibition kinetics for $\mathrm{AChE}$ and general esterase in $A$. mellifera and $A$. florea in response to exposure to carbosulfan, chlorpyrifos and pirimiphos-methyl.

\section{Conclusion}

This study sheds light on four enzymes in $A$. mellifera and $A$. florea. It advances our knowledge and understanding about effects of insecticides on honey bees at low concentrations in the environment. No significant differences occurred in the specific activities of GST, general esterase and oxidase between $A$. mellifera and $A$. florea. Carbosulfan and pirimiphosmethyl caused higher inhibition to AChE in both $A$. mellifera and A. florea. Overall, the tested insecticides demonstrated variable inhibition rates and patterns against the four enzymes, which revealed some of the negative effects of insecticides on honey bees. Thus, there is a need for developing new generations of agricultural pesticides that are safer on honey bees. In addition, further studies are warranted to evaluate effects of pesticides on A. florea in particular because it is a wild species and its numbers cannot be augmented by beekeepers unlike A. mellifera, which is kept in hives maintained by beekeepers.

\section{Acknowledgement}

The authors thank the Agriculture Research Stations (Kuwaitat), Abu Dhabi Food Control Authority (ADFCA), Al-Ain, UAE, for providing honey bees ( $A$. mellifera). In addition, the authors thank Mr. Ahmed Mahmoud Rajab for providing expert insights on honey bees and beekeeping.

\section{Funding Information}

Funding was provided by the Environmental Science Master's Program, College of Science, UAE University, Al-Ain, UAE.

\section{Author's Contributions}

Amal Ahmed Berjawi: Performed the experiments and participated in data analysis and paper writing.

Syed Salman Ashraf: Participated in designing the experiments, in data analysis and in paper writing.

Mohammad Ali Al-Deeb: Conceived and designed the experiments, participated in performing the experiments and in data analysis, provided reagents/materials and wrote the paper.

\section{Ethics}

This article is original and contains unpublished material. The corresponding author confirms that all of the other authors have read and approved the manuscript and no ethical issues involved.

\section{References}

Akca, I., C. Tuncer, A. Guler and I. Saruhan, 2009. Residual toxicity of 8 different insecticides on honey bee (Apis mellifera hymenoptera: Apidae). J. Anim. Vet. Adv., 8: 436-440.

Bradford, M.M., 1976. A rapid and sensitive method for the quantitation of microgram quantities of protein utilizing the principle of protein-dye binding. Anal. Biochem., 72: 248-254.

Chai, Y.X., G.Y. Liu and J.J. Wang, 2007. Toxicological and biochemical characterizations of AChE in Liposcelis bostrychophila Badonnel (Psocoptera: Liposcelididae). Pestic. Biochem. Physiol., 88: 197-202.

DOI: $10.1016 /$ j.pestbp.2006.11.003

Chauzat, M.P., J.P. Faucon, A.C. Martel, J. Lachaize and N. Cougoule et al., 2006. A survey of pesticide residues in pollen loads collected by honey bees in France. J. Econ. Entomol., 99: 253-262.

DOI: $10.1603 / 0022-0493-99.2 .253$ 
Choudhary, A. and D.C. Sharma, 2008. Dynamics of pesticide residues in nectar and pollen of mustard (Brassica juncea (L.) Czern.) grown in Himachal Pradesh (India). Environ. Monit. Assess., 144: 143-150. DOI: 10.1007/s10661-007-9952-3

Damayanthi, B.T. and S.H.P.P. Karunaratne, 2005. Biochemical characterization of insecticide resistance in insect pests of vegetables and predatory ladybird beetles. J. Natl. Sci. Found. Sri Lanka, 33: 115-122.

Dively, G.P. and A. Kamel, 2012. Insecticide residues in pollen and nectar of a cucurbit crop and their potential exposure to pollinators. J. Agric. Food Chem., 60: 4449-4456. DOI: 10.1021/jf205393x

Dou, W., J.J. Wang and Z.M. Zhao, 2006. Toxicological and biochemical characterizations of GSTs in Liposcelis bostrychophila Badonnel (Psocop., Liposcelididae). J. Applied Entomol., 130: 251-256. DOI: 10.1111/j.1439-0418.2006.01059.x

Ellman, G.L., K.D. Courtney, V. Andres and R.M. Feather-Stone, 1961. A new and rapid colorimetric determination of acetylcholinesterase activity. Biochem. Pharmacol., 7: 88-95.

Greenpeace, 2014. The bees' burden: An analysis of pesticide residues in comb pollen (Beebread) and trapped pollen pollen from honey bees (Apis mellifera) in 12 European countries.

Habig, W.H., M.J. Pabst and W.B. Jakoby, 1974. Glutathione S-transferases. The first enzymatic step in mercapturic acid formation. J. Biol. Chem., 249: 7130-7139.

Hagler, J.R., S. Mueller, L.R. Teuber, S.A. Machtley and A. Van Deynze, 2011. Foraging range of honey bees, Apis mellifera, in alfalfa seed production fields. J. Insect Sci., 11: 144-144.

DOI: 10.1673/031.011.14401

Hai-Hua, W., Y. Mei-Ling, G. Ya-Ping and M. En-Bo, 2005. Comparisons of properties of acetylcholinesterase from two field-collected populations of Oxya chinensis thunberg (Orthoptera: Acrididae) and the role of acetylcholinesterase in the susceptibility to malathion. Agr. Sci. China., 4: 47-53.

He, X., 2003. A continuous spectrophotometric assay for the determination of diamondback moth esterase activity. Arch. Insect Biochem. Physiol., 54: 68-76. DOI: 10.1002/arch.10103

Husain, D., M. Qasim, M. Saleem, M. Akhter and K. Khan, 2014. Bioassay of insecticides against three honey bee species in laboratory conditions. Cercet. Agron. Mold., 47: 69-79.

Ishaaya, I., 1993. Insect detoxifying enzymes: Their importance in pesticide synergism and resistance. Arch. Insect Biochem. Physiol., 22: 263-276. DOI: $10.1002 / \operatorname{arch} .940220119$
Josephy, P.D., T. Eling and R.P. Mason, 1982. The horseradish peroxidase-catalyzed oxidation of 3,5,3',5'-tetramethylbenzidine. Free radical and charge-transfer complex intermediates. J. Biol. Chem., 257: 3669-3675.

Kamanyire, R. and L. Karalliedde, 2004. Organophosphate toxicity and occupational exposure. Occup. Med. (Chic. Ill), 54: 69-75.

DOI: $10.1093 /$ occmed/kqh018

Khan, M.S., B. Kumari, H.R. Rohilla, H.D. Kaushik and R.K. Arora, 2004. Analysis of insecticide residues in honeys from apiary (Apis mellifera) and wild honey bee (Apis dorsata and Apis florea) colonies in India. J. Apic. Res., 43: 79-82. DOI: 10.1080/00218839.2004.11101115

Kostaropoulos, I., A.I. Papadopoulos, A. Metaxakis, E. Boukouvala and E. Papadopoulou-Mourkidou, 2001. Glutathione S-transferase in the defence against pyrethroids in insects. Insect Biochem. Mol. Biol., 31: 313-319. DOI: 10.1016/S0965-1748(00)00123-5

Lee, K., 1991. Glutathione S-transferase activities in phytophagous insects: Induction and inhibition by plant phototoxins and phenols. Insect Biochem., 21: 353-361. DOI: 10.1016/0020-1790(91)90001-U

Leibson, T. and M. Lifshitz, 2008. Organophosphate and carbamate poisoning: Review of the current literature and summary of clinical and laboratory experience in Southern Israel. Isr. Med. Assoc. J., 10: 767-770.

Li, X., M.A. Schuler and M.R. Berenbaum, 2007. Molecular mechanisms of metabolic resistance to synthetic and natural xenobiotics. Annu. Rev. Entomol., 52: 231-253.

DOI: 10.1146/annurev.ento.51.110104.151104

Papadopoulos, A., E. Lazaridou, G. Mauridou and M. Touraki, 2004. Glutathione S-transferase in the branchiopod Artemia salina. Mar. Biol., 144: 295-301.

Pasay, C., L. Arlian, M. Morgan, R. Gunning and L. Rossiter et al., 2009. The effect of insecticide synergists on the response of scabies mites to pyrethroid acaricides. PLoS Negl. Trop. Dis., 3: 1-8. DOI: 10.1371/journal.pntd.0000354

Pohorecka, K., P. Skubida, A. Miszczak, P. Semkiw and P. Sikorski et al., 2012. Residues of Neonicotinoid Insecticides in Bee Collected Plant Materials from Oilseed Rape Crops and their Effect on Bee Colonies. J. Apic. Sci., 56: 115-134. DOI: $10.2478 / \mathrm{v} 10289-012-0029-3$

Price, N.R., $1988 . \quad$ Insecticide-insensitive acetylcholinesterase from a laboratory selected and a field strain of housefly (Musca domestica) (L.). Comp. Biochem. Physiol. C, 90: 221-224.

Sanchez-Bayo, F. and K. Goka, 2014. Pesticide residues and bees - A risk assessment. PLoS One. DOI: 10.1371/journal.pone.0094482 
Smirle, M.J., 1990. The influence of detoxifying enzymes on insecticide tolerance in honey bee colonies (Hymenoptera: Apidae). J. Econ. Entomol., 83: 715-720. DOI: 10.1093/jee/83.3.715

Sogorb, M.A. and E. Vilanova, 2002. Enzymes involved in the detoxification of organophosphorus, carbamate and pyrethroid insecticides through hydrolysis. Toxicol. Lett., 128: 215-228. DOI: $10.1016 / \mathrm{S} 0378-4274(01) 00543-4$

Stapel, J.O., M. Cortesero and W.J. Lewis, 2000. Disruptive sublethal effects of insecticides on biological control: Altered foraging ability and life span of a parasitoid after feeding on extrafloral nectar of cotton treated with systemic insecticides.

Biol. Control, 17: 243-249.

DOI: $10.1006 /$ bcon.1999.0795

Stoner, K.A. and B.D. Eitzer, 2012. Movement of soilapplied imidacloprid and thiamethoxam into nectar and pollen of squash (Cucurbita pepo). PLoS One, 7: 1-5. DOI: 10.1371/journal.pone.0039114

Suh, Y.T. and J.H. Shim, 1988. Enzyme activities of a honeybee (Apis mellifear L.) associated with the degradation of some insecticdes. J. Korean Chem. Soc., 31: 241-248.

Tang, S.S. and G.G. Chang, 1996. Kinetic characterization of the endogenous glutathione transferase activity of octopus lens S-crystallin. J. Biochem., 119: 1182-1188.

Tiwari, S., K. Pelz-Stelinski, R.S. Mann and L.L. Stelinski, 2011. Glutathione transferase and cytochrome P450 (General Oxidase) activity levels in candidatus liberibacter asiaticus-infected and uninfected Asian citrus psyllid (Hemiptera: Psyllidae). Ann. Entomol. Soc. Am., 104: 297-305. DOI: $10.1603 / A N 10128$
Vanhaelen, N., F. Francis and E. Haubruge, 2004. Purification and characterization of glutathione Stransferases from two syrphid flies (Syrphus ribesii and Myathropa florae). Comp. Biochem. Physiol. Part B Biochem. Mol. Biol., 137: 95-100. DOI: $10.1016 /$ j.cbpc.2003.10.006

Visscher, P. and T. Seeley, 1982. Foraging strategy of honeybee colonies in a temperate deciduous forest. Ecology, 63: 1790-1801.

Wang, J.J., W.X. Cheng, W. Ding and Z.M. Zhao, 2004. The effect of the insecticide dichlorvos on esterase activity extracted from the psocids, Liposcelis bostrychophila and L. entomophila. J. Insect. Sci., 4: 23-23.

Westlake, G.E., A.R. Hardy and J.H. Stevenson, 1985. Effects of storage and pesticide treatments on honey bee brain acetyl cholinesterase activities. Bull. Environ. Contam. Toxicol., 34: 668-675. DOI: 10.1007/BF01609791

Wu, H., K. Zhu, Y. Guo, X. Zhang and E. Ma, 2008. Comparative studies of substrate and inhibitor specificity of glutathione S-transferases in six tissues of Oxya chinensis (Thunberg) (Orthoptera: Acrididae). Agric. Sci. China, 7: 462-468. DOI: $10.1016 / \mathrm{S} 1671-2927(08) 60090-5$

$\mathrm{Yu}$, S.J., 2004. Induction of detoxification enzymes by triazine herbicides in the fall armyworm, Spodoptera frugiperda (J.E. Smith). Pestic. Biochem. Physiol., 80: 113-122. DOI: $10.1016 /$ j.pestbp.2004.06.005

$\mathrm{Yu}$, S.J. and E.L. Hsu, 1993. Induction of detoxification enzymes in phytophagous insects: Role of insecticide synergists, larval age and species. Arch. Insect Biochem. Physiol., 24: 21-32.

DOI: $10.1002 /$ arch.940240103 